\title{
Владислав БЕЛОВ
}

\section{ГЕРМАНО-РОССИЙСКОЕ СОТРУДНИЧЕСТВО - ВЫЗОВЫ 2020 г. И ПЕРСПЕКТИВЫ 2021 г. ЧАСТЬ 1. ПОЛИТИЧЕСКИЕ АСПЕКТЫ}

\begin{abstract}
Аннотация. События 2020 г. оказали существенное влияние на все стороны политического и экономического сотрудничества Германии с Россией. Год начался с конструктивного политического диалога по ряду международных вопросов, который во второй половине года, когда ФРГ была председателем в Совете Евросоюза, оказался в глубоком кризисе, обусловленном т.н. «фактором Навального». Одновре́менно Берлин предложил выстраивать отношения с Россией в сфере безопасности с позиџии силь. Пандемия коронавируса, побудившая руководство обоих государств ограничить мобильность капитала и рабочей силь, а также резкое падение мировых иен на нефть негативно повлияли на взаимные товаропотоки, объём которых существенно сократился. На этом фоне продолжсилась инвестиционная активность немецких компаний в российских регионах. Обозначилась новая сфера кооперации - водородная энергетика. В сентябре 2020 г. начался Год Германии в России, а в декабре - перекрёстный Год экономики и устойчивого развития. В первой части автор анализирует политические итоги 2020 г. и начала 2021 г. и оченивает среднесрочные перспективы германо-российского сотрудничества в сфере политики. Во второй части рассматриваются экономические аспекты кооперации.
\end{abstract}

Ключевые слова: Германия, Россия, Евросоюз, политический диалог, германо-российское сотрудничество, безопасность.

Германия и Россия в 2020 г. - начале 2021 г. подтвердили свою роль политических и экономических лидеров в основных интеграционных моделях на евразийском континенте. ФРГ - в рамках Европейского союза, РФ - Евразийского экономического союза. Оба государства вносят основной вклад в формирование политического и хозяйственного пространства Большой Европы, во многом благодаря многочисленным кооперационным связям, определяя специфику этого сложнейшего процесса. Пандемия коронавируса, резкое падение мировых цен на энергоносители, а также ряд других факторов оказали существенное влияние на все сферы взаимодействия ФРГ и РФ. В российской и иностранной научной литературе пока отсутствуют комплексные исследования состояния и перспектив германо-российского сотрудничества в указанный период. Отдельные аспекты проанализированы автором настоящей статьи ${ }^{1}$, а также в ряде научных публикаций других исследователей ${ }^{1}$. Предлагаемый материал (в

(C) Белов Владислав Борисович - кандидат экономических наук, ведущий научный сотрудник, заместитель директора по научной работе, руководитель Отдела страновых исследований, руководитель Центра германских исследований ИЕ РАН. Адрес: 125009, Россия, Москва, ул. Моховая, д. 11, стр. 3.E-mail: vladisbelov@yandex.ru.

Статья поступила в редакиию: 07.02.2021.

${ }^{1}$ Белов В.Б. Новые водородные стратегии ФРГ и ЕС: перспективы кооперации с Россией // Современная Европа. 2020. №6. C. 65-76. DOI: 10.15211/soveurope520206576; Белов В.Б. Специальные инвестиционные контракты и российско-германское экономическое сотрудничество. Часть вторая // Современная Европа. 2020. №1. С. 146- 
двух частях) восполняет этот пробел.

\section{Международная повестка - Сирия, Ливия, Иран, Украина}

Впервые в истории двусторонних отношений федеральный канцлер А. Меркель и глава внешнеполитического ведомства Германии X. Маас уже в первой половине января посетили Москву. Официальная цель визита, согласованного сторонами в конце 2019 г. после негативных событий декабря (взаимная высылка дипломатов), состояла в обсуждении вопросов международной повестки. Накануне встречи обострилась ситуация на Ближнем и Среднем Востоке (ракетный обстрел американских баз в Ираке, ответные удары США по лагерям «Хезболла» в Сирии и Ираке, нападение на американское посольство в Багдаде, последующее убийство иранского генерала К. Сулеймани и ракетная атака Ирана базы американских ВВС «Айн аль-Асад», во время которой был сбит украинский пассажирский самолёт; Турция, поддерживая официальный Триполи, ввела войска в Ливию). Именно она стала основной. В ходе переговоров Москва пообещала Берлину оказать поддержку в проведении мирной конференции с участием конфликтующих в Ливии сторон и активизировать т.н. «берлинский мирный процесс», одной из главных целей которого было прекращение огня на ливийской территории ${ }^{2}$. Среди прочего В.В. Путин подробно обсудил с А. Меркель свои переговоры с президентом Турции об урегулировании ситуации в Ливии, которые прошли 3 января.

В свою очередь, высоко оценивая ведущую роль России в сирийском конфликте, бундесканцлер донесла до российских партнёров пожелание содействовать деэскалации кризисной ситуации в ближневосточном регионе, подчеркнув, что военное решение для Сирии исключено - должны быть исключительно переговоры, на которые Германия и делает ставку. Одновре́менно Берлин и Москва подтвердили заинтересованность в сохранении Совместного всеобъемлющего плана действий (СВПД) по иранской ядерной программе. В.В. Путин напомнил немецким партнёрам, что в условиях американских санкций Иран надеется на поддержку европейских стран, обещавших создать специальный независимый от США финансовый механизм для расчётов по взаимным торговым поставкам.

Немецкий лидер высказала поддержку проекту «Северный поток - 2», реализация которого в январе 2020 г. была приостановлена. Подтвердив своё прежнее отрицательное отношение к экстерриториальным санкциям Соединённых Штатов, направленным против участвующих в строительстве газопровода компаниям, она выразила надежду на его успешное завершение ${ }^{3}$.

«Нормандский формат» в январских переговорах отошёл на второй план. А. Меркель, назвав итоги декабрьской встречи в Париже частично успешной и сказав, что удовлетворена

157. DOI: 10.15211/soveurope12020146157; Белов В.Б. «Северный поток - 2» в контексте Мюнхенской конференции по безопасности. Аналитические записки ИЕ РАН. 2020. №4(187). DOI: 10.15211/analytics42020; Белов В.Б. Водородная энергетика - новая ниша российско-германской кооперации // Аналитические записки ИЕ PAH. 2020. №37(220). DOI: 10.15211/analytics372020; Белов В.Б. РФ - ФРГ: кризис политического доверия как фактор асимметрии отношений. РСМД. 02.11.2020 URL: https://russiancouncil.ru/analytics-and-comments/ analyti cs/rf-frg-krizis-politicheskogo-doveriva-kak-faktor-asimmetrii-otnosheniv/: Белов В.Б. Роль и место России в актуальной внешнеполитической повестке ФРГ. НГ. 27.12.2020. URL: https://www.ng.ru/dipkurer/2020-12-27/9 8050 germany.html (дата обращения 30.01.2021).

Т Тимофеев И.Н. Россия - Германия: восприятие и мотивы. РСМД. 08.10.2020. URL: https://russiancouncil.ru/ analytics-and-comments/analytics/rossiya-germaniya-vospriyatie-i-motivy/; Тренин Д. Последняя страница. Как дело Навального изменило отношения России и Германии. 14.09.2020. URL: https://carnegie.ru/commentary/82690; Фишер С. От газопровода до Навального. Чего Кремль не понимает про Германию. 25.09.2020. URL: https://carnegie.ru/commentary/82783 (дата обращения 21.01.2021).

219 января 2020 г. В.В. Путин наряду с другими мировыми лидерами принял участие в Берлинской конференции по Ливии.

${ }_{3}^{5}$ Более подробно этот вопрос будет освещён во второй части статьи. 
проведённым в конце года обменом пленными и предпринимаемыми усилиями по режиму прекращения огня, признала существование сложностей в урегулировании украинского конфликта.

Президент ФРГ Франк-Вальтер Штайнмайер, открывая 14 февраля 2020 г. очередную Мюнхенскую конференцию по безопасности, сделал украинскую тематику в своей речи одной из центральных, заявив: «Россия, справедливо или нет уязвленная и отдалившаяся, не только аннексировала Крым без оглядки на международное право. Она снова сделала инструментом политики военную силу и насильственное изменение границ на европейском континенте» ${ }^{1}$. Другим его посланием стало то, что Европейский союз не должен ограничиваться «осуждающими заявлениями и санкциями». Брюссель нуждается в новой политике по отношению к Москве, но при этом его «размышления о будущих отношениях с Россией не должны вестись без или за счёт стран и народов Центральной Европы»².

Берлину и Москве в течение 2020 г. не удалось обеспечить полное выполнение договорённостей декабрьского «нормандского» саммита на высшем уровне в Париже ${ }^{3}$. В апреле 2020 г. главы внешнеполитических ведомств Германии, Франции, России и Украины констатировали отсутствие прогресса в этом направлении. Заместитель руководителя Администрации президента РФ Д.Н. Козак в мае посетил немецкую столицу, обсудив с руководством ФРГ возможные пути решения проблем, но визит закончился безрезультатно. 3 июля в Берлине на встрече политических советников глав правительств и государств стран «нормандской четвёрки» была достигнута договорённость об обеспечении режима тишины и прекращения огня, который с конца июля в целом соблюдался. В последующие месяцы удалось избежать масштабных перестрелок. В сентябре участники очередной встречи подчеркнули необходимость и дальше выполнять оговорённые механизмы. 12 января 2021 г. Д.Н. Козак, подводя итоги очередной встречи в Берлине (была запланирована политическими советниками там же в ноябре 2020 г.), заявил, что окончательных решений ни по одному из пунктов переговоров достичь не удалось, особо отметив при этом договорённость о подготовке новых принципиальных подходов к формированию дорожной карты в Трёхсторонней контактной группе по всеобъемлющему урегулированию конфликта ${ }^{4}$.

Основная причина отсутствия прогресса в течение года - незаинтересованность украинского высшего руководства в реализации положений Минских соглашений, а также ограниченные возможности Берлина и Парижа воздействовать на Киев ${ }^{5}$. По этой причине сложно прогнозировать, когда состоится очередной нормандский саммит и что можно ожидать от него.

Лидеры Германии и России после января 2020 г. в течение года по телефону (например, 3 марта, 9 июня, 14 июля, 17 августа, 7 декабря), поддерживая рабочий диалог, продолжили обсуждение ключевых аспектов международной ситуации.

Очевидно, тематика Ближнего и Среднего Востока, Украины будет определять основную повестку международных вопросов, соответственно, их обсуждений немецкими и российски-

\footnotetext{
${ }^{1}$ Гончаренко Р. Какие сигналы Германия посылает России с Мюнхенской конференции. 15.02.2020. URL: https://p.dw.com/p/3Xo0D (дата обращения 21.01.2021).

${ }^{2}$ Там же.

${ }^{3}$ В принятом 9 декабря 2019 г. в итоговом заявлении говорится об установлении полноценного перемирия, внесении в законодательство Украины поправок в соответствии с «формулой Штайнмайера» и о закреплении особого статуса Донбасса в конституции украинского государства.

${ }^{4}$ Козак о переговорах в нормандском формате в Берлине заявил, что «похвастаться нечем». ТАСC. 12.01.2021. URL: https://tass.ru/politika/10445787 (дата обращения 21.01.2021).

${ }^{5}$ Например, украинские участники «берлинских встреч» в 2020 г. так и не прояснили, когда будет готов проект поправок в конституцию по децентрализации. При этом президент Украины В.А. Зеленский считает, его государство выполнило все парижские договорённости лидеров «нормандской четвёрки». Об этом в декабре 2020 г. он сообщил в телефонном разговоре с французским лидером Э. Макроном.
}

Научно-аналитический вестник ИЕ РАН, 2021, №1 
ми лидерами в 2021 г. Берлин заинтересован в этом важном для него факторе, позволяющем Германии постепенно укреплять роль самостоятельного внешнеполитического актора, способного продвигать свои интересы и участвовать в решении важнейших проблем на международной арене.

\section{Двусторонние отношения в контексте ЕС}

Германия рассматривает отношения с Россией в контексте членства в Евросоюзе и в своих программных документах говорит о них как о «европейско-немецко-российских отношениях». Такое позиционирование предполагает наличие у Берлина концептуального видения основ многостороннего сотрудничества с ведущим партнёром на востоке постсоветского евразийского пространства - чего-то сравнимого с известной «восточной политикой» ФРГ в 70-80 гг. прошлого века. Но до сих пор такая концепция официально представлена не была. На сегодняшний день её заменяют известные «пять принципов Могерини», принятые Брюсселем в марте 2016 г. По образному выражению А.В. Кортунова, они стали своего рода наименьшим общим знаменателем разнонаправленных позиций членов ЕС, зафиксировавшим компромисс между сторонниками жесткой и приверженцами мягкой линии на российском направлении и в основном опирающимся на четвёртый принцип «избирательного взаимодействия» ${ }^{1}$. Спустя почти пять лет ситуация не изменилась. Новые комплексные подходы к отношениям с Россией ни Берлин, ни Брюссель не озвучили.

Во второй половине 2020 г. Германия возглавила Совет Европейского союза, что давало Берлину возможность предложить более развёрнутые представления о восточном векторе внешней политики ЕС. Но он им не воспользовался.

Накануне председательства А. Меркель выступила в Берлине с программной речью, в которой особое внимание уделила России. Лейтмотивом стал постулат о приоритете ценностного подхода ЕС и Германии в отношениях с ней. С одной стороны, бундесканцлер указала на наличие «множества веских причин» для их поступательного развития (в т.ч. географическая близость и общая история, глобальные вызовы и взаимные экономические отношения). С другой стороны, наряду с таким конструктивом она всегда придерживалась необходимости критического диалога с РФ, в т.ч. потому, что Россия «неоднократно нарушала ... канон ценностей и правил», состоящий из приверженности Хельсинкскому Заключительному акту, Европейской конвенции о правах человека и понимания того, что «в международных отношениях действует не закон сильнейшего, а сила закона»: «Россия создала пояс неразрешённых конфликтов в непосредственной близости от неё и аннексировала украинский полуостров Крым в нарушение международного права. Она поддерживает марионеточные режимы в некоторых частях восточной Украины и атакует западные демократии гибридными средствами, включая Германию. Нет никаких сомнений в том, что Россия будет и дальше нас беспокоить в период председательства в Совете ЕС» ${ }^{2}$. Поэтому Берлин будет реагировать на такие действия, фиксировать нарушения со стороны Москвы и выступать за сохранение санкций Евросоюза в случае отсутствия прогресса в Минских соглашениях. Одновре́менно Меркель подчеркнула, что председательство даёт возможность придать новый импульс двусторонним отношениям,

\footnotetext{
${ }^{1}$ Кортунов А.В. От «избирательного взаимодействия»- к «просвещённому реализму»? РСМД. 06.02.2020. URL: https://russiancouncil.ru/analytics-and-comments/analytics/ot-izbiratelnogo-vzaimodeystviya-k-prosveshchenno mu-realizmu/ (дата обращения 21.01.2021).

${ }^{2}$ Rede von Bundeskanzlerin Merkel im Rahmen der Veranstaltung «Außen- und Sicherheitspolitik in der deutschen EU-Ratspräsidentschaft» der Konrad-Adenauer-Stiftung am 27. Mai 2020. Donnerstag. 28.05.2020. URL: https:// www.bundesregierung.de/breg-de/aktuelles/rede-von-bundeskanzlerin-merkel-im-rahmen-der-veranstaltung-aussen-und -sicherheitspolitik-in-der-deutschen-eu-ratspraesidentschaft-der-konrad-adenauer-stiftung-am-27-mai-2020-1755884 (дата обращения 30.11.2020).
}

Научно-аналитический вестник ИЕ РАН, 2021, №1 
включая не только вопросы Ближнего Востока, но и защиты климата и глобального здравоохранения: «Таким образом, мы выражаем наши ценности, как с помощью наших принципов, так и наших обязательств» ${ }^{1}$.

В самой программе председательства России был отведён один маленький абзац. В нём выражена поддержка Высокому представителю по иностранным делам и внешней политике, который «привержен активному построению отношений между ЕС и Россией на основе пяти принципов и оценке их выполнения» 2 .

Никаких итогов по восточному вектору своей работы в качестве председателя Берлин не подвёл. Во время правительственного часа в Бундестаге в середине декабря А. Меркель, отвечая на вопрос заместителя фракции «Альтернативы для Германии» Т. Хрупаллы, сказала, что необходимость перезагрузки германо-российских связей отсутствует ${ }^{3}$.

Очевидно, что по состоянию на начало 2021 г. новые концептуальные подходы к отношениям Евросоюза с Россией ни Берлин, ни Брюссель не озвучили. С большой долей вероятности они пока не разработаны и/или по ним отсутствует консенсус стран-членов.

4-6 февраля 2021 г. Высокий представитель по иностранным делам и внешней политике ЕС М. Боррель, впервые с 2019 г. посетивший Москву, и глава МИД РФ С.В. Лавров обсудили отношения между Евросоюзом и Россией, а также глобальную геополитическую обстановку. Среди прочего речь шла о возможном взаимодействии в сферах трансграничного сотрудничества, исследований и инноваций, совместного решения глобальных проблем, касающихся изменения климата и общественного здравоохранения. Обсуждались вопросы сотрудничества в рамках СВПД по иранской ядерной программе, ближневосточного мирного процесса, а также ситуации с правами человека, неправительственными организациями и гражданским обществом в РФ.

\section{Фактор «берлинского пациента»}

В начале 2020 г. силовые ведомства констатировали, что с большой долей вероятности за атакой на сервер Бундестага в конце апреля - начале мая 2015 г. стоит Россия, а именно Главное разведывательное управление. Неопровержимых доказательств за пять лет немецким следователям найти так и не удалось. Тем не менее, с учётом истечения срока давности 5 мая 2020 г. Генпрокуратура ФРГ объявила в розыск подозреваемого в причастности к кибератаке российского гражданина. Информация «о преступных действиях России» была весьма негативно воспринята А. Меркель. Можно сказать, что для неё это стало глубоким личным оскорблением. Канцлер особо остановилась на этом событии во время правительственного часа в Бундестаге в середине мая 2020 г. В один ряд с этим событием она поставила такие «преступные» действия Москвы как отравления Скрипалей в Солсбери в марте 2018 г. и убийство в Берлине в августе 2019 г. Хангошвили. Неожиданно для всех в конце августа к этому добавился «фактор Навального».

Отравленный российский блогер, спасённый благодаря решительным действиям экипажа самолёта и врачей омской больницы, был переправлен для дальнейшего лечения в Берлин, где стал личным гостем А. Меркель. С самого начала в немецком общественно-политическом дискурсе лейтмотивом стало утверждение о покушении на жизнь ведущего оппозиционера России и ответственности за это преступление Кремля. Антироссийская кампания до-

\footnotetext{
${ }^{1}$ Ibid

${ }^{2}$ Gemeinsam. Europa wieder stark machen. Programm der deutschen EU-Ratspräsidentschaft. 1. Juli bis 31. Dezember 2020. Auswärtiges Amt. Berlin. S. 22. URL: https://www.eu2020.de/blob/2360246/d0e7b758973f0b1f56e74730bfdaf9 9d/pdf-programm-de-data.pdf (дата обращения 30.11.2020).

${ }^{3}$ См.: Белов В.Б. Роль и место России... Цит. соч.
}

Научно-аналитический вестник ИЕ РАН, 2021, №1 
стигла своего пика после обнаружения экспертами лаборатории бундесвера элементов боевого отравляющего вещества из группы «Новичок» в организме А. Навального (специалисты клиники «Шарите» «желаемого вещества» найти не смогли). По инициативе Берлина Евросоюз 15 октября 2020 г. принял т.н. «химические» санкции ${ }^{1}$, добавив к ним 17 октября персональные ограничительные меры из-за кибератак на Бундестаг.

Попытки Москвы добиться от Берлина взаимопонимания и готовности к взаимодействию в отношении расследования причин отравления российского гражданина закончились безуспешно.

Необоснованные, по мнению Кремля, обвинения со стороны руководства Германии и ЕС побудили министра иностранных дел РФ С.В. Лаврова в середине октября сделать резкое заявление о недопустимости такого давления, которое может привести к прекращению общения. Послание было услышано и стороны стали постепенно восстанавливать утерянный диалог. Негативная риторика ведущих немецких политиков несколько смягчилась.

Важно, что сохранился налаженный за последние годы рабочий диалог В.В. Путина и А. Меркель. Для общения лидеров Германии и России с весны 2017 г. обозначилось понимание не только красных линий, но и сущностных/предметных характеристик двусторонних отношений и их роли в нынешнем и будущем развитии евразийского континента. Главе немецкого правительства при сохранении общего критического настроя до последнего времени удавалось демпфировать антироссийские настроения и несколько сдерживать их.

Тем не менее, «фактор берлинского пациента», будучи составной частью ценностного критического германского внешнеполитического вектора, стал катализатором резкого углубления кризиса двустороннего политического диалога ${ }^{2}$. Ситуация ещё больше ухудшилась после возвращения А. Навального в Россию в январе 2021 г., его ареста и массовых протестов в ряде российских городов. Практически весь немецкий политический истэблишмент, включая А. Меркель, премьер-министра Баварии и председателя ХСС М. Зёдера, избранного 16 января 2021 г. председателя ХДС А. Лашета ${ }^{3}$ и нового координатора межобщественного сотрудничества с Россией, Центральной Азией и странами Восточного партнёрства депутата Бундестага (СДПГ) Й. Заатхоффа ${ }^{4}$, занял жёсткую позицию по отношению к Кремлю, требуя немедленного освобождения «ведущего российского оппозиционера».

Этот вопрос стал одним из основных в рамках упомянутого визита в Москву М. Борреля, заявившего, что ЕС ожидает «немедленного и безоговорочного освобождения господина Навального вместе с лицами, произвольно задержанными во время недавних демонстраций». Своеобразным ответом российской стороны стало объявление 5 февраля персонами нон грата (из-за участия в несанкционированных акциях протеста) трёх дипломатов посольств Польши, Швеции и Германии, что ещё больше обострило напряжённость в отношениях Брюсселя, а также других европейских столиц и Москвы. А. Меркель осудила такую высылку как «необоснованную», подчеркнув, что «это ещё один аспект, который можно наблюдать прямо сейчас, когда Россия довольно далека от верховенства права». Х. Маас пообещал дать адекват-

\footnotetext{
${ }^{1}$ Основой для принятия ограничительных мер стал механизм, разработанный Евросоюзом в октябре 2018 г. после известных событий в Солсбери в марте того же года.

${ }_{3}^{2}$ В декабре 2020 г. Москва, как и обещала, приняла санкции в отношении ряда функционеров ФРГ и ЕС.

${ }^{3}$ Избранный 16 января 2021 г. на съезде христианских демократов новый председатель ХДС Армин Лашет считается политиком, занимающим конструктивную позицию по отношению к России и «понимающим её» («Russlandversteher»). См.: Белов В.Б. Выборы нового председателя Христианско-демократического союза Германии // Аналитические записки ИЕ РАН. 2021. №1(231). DOI: 10.15211/analytics12021

${ }^{4}$ Йоханн Заатхофф - член Комитета Бундестага по экономике и энергетике, а также Комитета по продовольствию и сельскому хозяйству; координатор парламентской фракции СДПГ по вопросам энергетической политики. 26 августа 2020 г. он стал новым координатором межобщественного сотрудничества с Россией, сменив на этой должности Д. Визе.
} 
ный ответ на такое решение Москвы, наносящий вред отношениям РФ с ЕС

\section{Россия как угроза европейской безопасности}

Ухудшение политического диалога на высшем уровне оказало негативное влияние на образ России, содействуя её восприятию как агрессивного государства. Этим воспользовалась федеральный министр обороны Аннегрет Крамп-Карренбауэр. В рамках формирования нового оборонного бюджета осенью 2020 г. она активно продвигала тезис о российской угрозе и необходимости активно противостоять ей.

Выступая в Бундестаге 25 ноября глава оборонного ведомства заявила: «Факт, что российская сторона вложила значительные инвестиции в модернизацию своих вооружённых сил, что она располагает новыми видами вооружений, что угроза стала более явственной. Я рекомендую провести на эту тему переговоры с коллегами из стран Балтии, Швеции, Центральной и Восточной Европы». Поэтому для укрепления оборонного потенциала НАТО, а также усиления позиций Германии и партнёров необходимо вести переговоры с Москвой по вопросам разоружения с позиции силы: «Эта всегда была хорошая позиция германской внешней политики, и так должно остаться в будущем» ${ }^{2}$.

По всей видимости, министр опиралась на итоги анализа военных и гибридных угроз, который эксперты Разведывательного и ситуационного центра EC (EU INTCEN) провели в соответствии с задачами, поставленными Берлином в рамках своего председательства в Совете EC. На заседании комитета по иностранным делам и подкомитета по вопросам безопасности и обороны Европарламента 14 июля 2020 г. она указала на необходимость исследовать восприятие России государствами Евросоюза как в свете её нового военного потенциала, так и поведения. Министр выразила надежду, что к 2022 г. ЕС сможет разработать новый инструмент оборонной политики - «стратегический компас», который объединит отдельные подходы в одну единую стратегию ${ }^{3}$. Накануне этого заседания, 23 июня 2020 г., генеральный секретарь НАТО Й. Столтенберг в интервью Deutsche Welle к основным угрозам мировой безопасности, наряду с терроризмом и «последствиями подъёма Китая», отнёс «более напористую Россию» с её «агрессивными действиями в отношении Украины». Указав на необходимость продолжать выделять средства для противостояния подобным вызовам, он подчеркнул одну из ведущих ролей Германии в Североатлантическом альянсе, которая является «очень сильным и важным союзником» с крупнейшим оборонным бюджетом в Евросоюзе и третьим по величине в $\mathrm{HATO}^{4}$.

Действительно, на ФРГ приходится около 10\% финансирования расходов этой организации, и она стремится сохранить такой статус-кво. В своей статье в журнале Focus в январе 2021 г. А. Крамп-Карренбауэр обосновывает важность финансирования новых проектов в рамках НАТО изменившимися новыми реалиями безопасности, одной из которой «является массированное вооружение России на восточной границе НАТО». В этом контексте она указывает, что важно придерживаться политики сдерживания (die Abschreckung) как предпосылки понимания поведения «с позиции силы», тем самым подтверждая свою приверженность

\footnotetext{
${ }^{1}$ Russland weist Diplomaten aus Deutschland, Schweden und Polen aus. 05.02.2021. URL: https://www.sueddeutsche. $\mathrm{de} /$ politik/putin-nawalny-diplomaten-1.5197449 (дата обращения 21.01.2021).

${ }_{2}^{2}$ Цит. по: Министр обороны ФРГ заявила, что угроза со стороны России стала очевиднее. ТАСС. 25.11.2020. URL: https://tass.ru/mezhdunarodnaya-panorama/10096525 (дата обращения 21.01.2021).

${ }^{3}$ Шейко Ю. Германия организует на уровне ЕС анализ угроз со стороны России. 14.07.2020. URL: https://p.dw. $\mathrm{com} / \mathrm{p} / 3 \mathrm{fJX0}$ (дата обращения 21.01.2021).

4 Мыльников П. Генсек НАТО отнёс Россию и Китай к угрозам безопасности. 23.06.2020. URL: https://p.dw.com/p/3eEhq (дата обращения 21.01.2021).
}

Научно-аналитический вестник ИЕ РАН, 2021, №1 
ранее высказанному тезису ${ }^{1}$.

Директор Департамента информации и печати МИД РФ М. Захарова, критикуя доктринально-директивный характер таких оценок, выразила надежду, что в Берлине возобладает реализм в стратегии применительно к России, которая готова «к взаимоуважительному и откровенному диалогу с ФРГ по самому широкому спектру актуальных международных проблем и двусторонних вопросов на основе взаимопонимания» ${ }^{2}$.

Смена администрации в Вашингтоне стала новым фактором, определяющим позицию Германии в отношениях НАТО и России. В упомянутой статье министр обороны высказала мнение, что Берлин в 2021 г. сможет примирить «трансатлантическое и европейское». По её мнению, это не только усилит европейский военно-технический потенциал, но и поможет понять ценность Америки для безопасности Европы ${ }^{3}$.

В середине января 2021 г. Североатлантический альянс возложил ответственность за проблемы с реализацией Договора об открытом небе (ДОН) на российское руководство ${ }^{4}$. Берлин, выразив сожаление относительно решения Москвы начать процедуру выхода из ДОН, призвал к сохранению конструктивного диалога о будущем договора. В конце декабря 2020 г. глава германского внешнеполитического ведомства Х. Маас вместе с 15 коллегами из стран Евросоюза в совместном послании министру иностранных дел РФ выразил желание соблюдать ДОН и обеспечивать его выполнение в полном объёме. В январе МИД ФРГ подтвердил свою готовность добиваться сохранения и модернизации контроля как над обычными, так и ядерными вооружениями в Европе 5 .

В заключение отметим, что в 2020 г. в медийном пространстве отсутствовала информация о деятельности межведомственной Рабочей группы высокого уровня по вопросам политики безопасности (РГВУ). Можно предположить, что входящие в её компетенцию вопросы обсуждались в режиме рабочего общения экспертов соответствующих ведомств.

Германия вписала фактор «берлинского пациента» в среднесрочную стратегию оказания давления на Кремль по линии ценностей и прав человека. Официальный Берлин будет его использовать и до, и после выборов в Бундестаг. В рамках предвыборной кампании ещё в большей степени это относится к блоку ХДС/ХСС и партии «Союз 90/Зелёные» - основным претендентам на формирование будущей правительственной коалиции. Хотя внешнеполитические вопросы не относятся к приоритетным в партийной борьбе за места в Бундестаге, такая риторика будет способствовать закреплению германо-российского политического диалога в нижней точке. Выход из этой негативной ситуации следует ожидать не ранее 2022 г.

По итогам будущих коалиционных переговоров будет понятно насколько официальный Берлин готов предложить новые концептуальные подходы к отношениям с Россией на пери-

\footnotetext{
${ }^{1}$ Kramp-Karrenbauer Annegret. Verteidigung, eine Kernaufgabe des Staates. 10.01.2021. URL: https://www.focus.de/ die-welt-2021/die-welt-in-2021-verteidigung-eine-kernaufgabe-des-staates_id_12776324.html (дата обращения 21.01.2021).

2 Захарова: попытки ФРГ оправдать курс НАТО на конфронтацию с Россией чреваты катастрофой. ТАСС. 15.01.2021. URL: https://tass.ru/politika/10468755 (дата обращения 21.01.2021).

${ }_{3}$ Kramp-Karrenbauer... Op. cit.

427 января 2021 г. генсек НАТО, обращаясь к министрам обороны стран - членов организации, повторил свои основные летние тезисы в отношении России, включив её «агрессивные действия» в число основных вызовов HATO на ближайшие годы. В этом плане риторика германского министра обороны полностью соответствует критической позиции Североатлантического альянса.

5 Ромашенко С. Германия сожалеет о выходе России из Договора по открытому небу. DW. 15.01.2021. URL: https://www.dw.com/ru/germanija-sozhaleet-o-vyhode-rossii-iz-dogovora-po-otkrytomu-nebu/a-56243580 (дата обращения 21.01.21).
} 
од до 2025 г. - как на двустороннем уровне, так и на уровне ЕС.

Уход А. Меркель, выстроившей содержательный рабочий диалог с В.В. Путиным и сдерживающей влияние антироссийских настроений на политическое сотрудничество, будет несколько компенсирован достаточно конструктивным подходом нового федерального канцлера, которым с высокой долей вероятности станет или М. Зёдер или А. Лашет. Им предстоит противостоять негативному отношению к российскому руководству зелёных - возможных партнёров по будущей коалиции, традиционно жёстко критикующих Москву по линии прав человека и демократических ценностей.

В 2021 г. сохранится взаимодействие по международному вектору, в котором основное место, наряду с Нормандским форматом, по-прежнему будет занимать сирийская, ливийская и иранская тематика. ФРГ сохранит заинтересованность во взаимодействии с РФ, которое содействует укреплению её внешнеполитических позиций. Одновременно Берлин продолжит использовать фактор «растущей российской угрозы» для обоснования роста расходов на оборону и восстановления трансатлантического партнёрства в сфере безопасности. В этом отношении ещё более актуальным становится активизация диалога в рамках Совета НАТО-РФ и деятельность РГВУ (в т.ч. по вопросам противодействия терроризму и наркотрафику).

\section{Список литературы}

Белов В.Б. Роль и место России в актуальной внешнеполитической повестке ФРГ // НГ. 27.12.2020. URL: https://www.ng.ru/dipkurer/2020-12-27/9_8050_germany.html (дата обращения 21.01.2021).

Белов В.Б. РФ - ФРГ: кризис политического доверия как фактор асимметрии отношений // РСМД. 02.11.2020. URL: https://russiancouncil.ru/analytics-and-comments/analytics/rf-frg-krizis -politicheskogo-doveriya-kak-faktor-asimmetrii-otnosheniy/ (дата обращения 21.01.21).

Кортунов А.В. От «избирательного взаимодействия» - к «просвещённому реализму»? // РСМД. 06.02.2020. URL: https://russiancouncil.ru/analytics-and-comments/analytics/otizbiratelnogo-vzaimodeystviya-k-prosveshchennomu-realizmu/ (дата обращения 21.01.2021).

Тимофеев И.Н. Россия - Германия: восприятие и мотивы // РСМД. 08.10.2020. URL: https://russiancouncil.ru/analytics-and-comments/analytics/rossiya-germaniya-vospriyatie-i-motivy/ (дата обращения 21.01.2021).

Тренин Д. Последняя страница. Как дело Навального изменило отношения России и Германии // Московский центр Карнеги. 14.09.2020. URL: https://carnegie.ru/commentary/82690 (дата обращения 21.01.2021).

Фишер С. От газопровода до Навального. Чего Кремль не понимает про Германию // Московский центр Карнеги. 25.09.2020. URL: https://carnegie.ru/commentary/82783 (дата обращения 21.01.2021).

\section{References}

Belov, V.B. RF-FRG: krizis politicheskogo doveriya kak faktor asimmetrii otnosheniy [RFFRG: the crisis of political trust as a factor of asymmetry in relations]. RIAC. December 27, 2020. Available at: https://russiancouncil.ru/analytics-and-comments/analytics/rf-frg-krizis-politicheskogo -doveriya-kak-faktor-asimmetrii-otnosheniy/ (accessed 30.01.2021). (In Russian).

Belov, V.B. Rol' i mesto Rossii v aktual'noy vneshnepoliticheskoy povestke FRG [The role and place of Russia in the current foreign policy agenda of the FRG]. NG. December 27, 2020. Available at: https://www.ng.ru/dipkurer/2020-12-27/9_8050_germany.html (accessed 30.01.2021). (In 
Russian).

Fischer, S. What Russia Doesn't Get About Germany? Carnegie.ru. September 16, 2020. Available at: https://carnegie.ru/commentary/82769 (accessed 21.01.2021).

Fisher, S. Ot gazoprovoda do Naval'nogo. Chego Kreml' ne ponimayet pro Germaniyu [From the gas pipeline to Navalny. What the Kremlin doesn't understand about Germany]. Carnegie.ru. September 25, 2020. Available at: https://carnegie.ru/commentary/82783 (accessed 21.01.2021). (In Russian).

Kortunov, A.V. Ot «izbiratel'nogo vzaimodeystviya» - $\mathrm{k}$ «prosveshchennomu realizmu»? [From «selective interaction» to «enlightened realism»?] RIAC. February 6, 2020. Available at: https://russiancouncil.ru/analytics-and-comments/analytics/ot-izbiratelnogo-vzaimodeystviya-kprosveshchennomu-realizmu/ (accessed 21.01.2021). (In Russian).

Kramp-Karrenbauer, Annegret. Verteidigung, eine Kernaufgabe des Staates [Defense, a core task of the state]. Focus. January 10, 2021. Available at: https://www.focus.de/die-welt-2021/diewelt-in-2021-verteidigung-eine-kernaufgabe-des-staates_id_12776324.html (accessed 21.01.2021). (In German).

Timofeyev, I.N. Rossiya - Germaniya: vospriyatiye i motivy [Russia - Germany: perception and motives]. RIAC. October 8, 2020. Available at: https://russiancouncil.ru/analytics-andcomments/analytics/rossiya-germaniya-vospriyatie-i-motivy/ (accessed 21.01.2021). (In Russian).

Trenin, D. Poslednyaya stranitsa. Kak delo Naval'nogo izmenilo otnosheniya Rossii i Germanii [Last page. How the Navalny case changed the relationship between Russia and Germany]. Carnegie.ru. September 14, 2020. Available at: https://carnegie.ru/commentary/82690 (accessed 21.01. 2021). (In Russian).

Trenin, D. Russian-German Relations: Back to the Future. Carnegie.ru. September 16, 2020. Available at: https://carnegie.ru/commentary/82713 (accessed 21.01.2021).

Rede von Bundeskanzlerin Merkel im Rahmen der Veranstaltung «Außen- und Sicherheitspolitik in der deutschen EU-Ratspräsidentschaft» der Konrad-Adenauer-Stiftung am 27. Mai 2020 [Speech by Chancellor Merkel at the event «Foreign and Security Policy in the German EU Council Presidency» of the Konrad Adenauer Foundation on May 27, 2020]. Donnerstag, 28. Mai 2020 in Berlin. Available at: https://www.bundesregierung.de/breg-de/aktuelles/rede-von-bundeskanzlerinmerkel-im-rahmen-der-veranstaltung-aussen-und-sicherheitspolitik-in-der-deutschen-eu-ratspraesid entschaft-der-konrad-adenauer-stiftung-am-27-mai-2020-1755884 (accessed 21.01.2021). (In German).

Gemeinsam. Europa wieder stark machen. Programm der deutschen EU-Ratspräsidentschaft. 1. Juli bis 31. Dezember 2020 [Together. Make Europe strong again. Program of the German EU Council Presidency. July 1 to December 31, 2020]. Auswärtiges Amt. Berlin. Available at: https:// www.eu2020.de/blob/2360246/d0e7b758973f0b1f56e74730bfdaf99d/pdf-programm-de-data.pdf (accessed 21.01.2021). (In German).

\section{German-Russian Cooperation - Challenges of 2020 and Prospects for 2021. Part 1. Political aspects}

Author. Vladislav Belov, Candidate of Sciences (Economics), Deputy Director of IE RAS, Head of the Department for Countries Studies, Head of the Center for German Studies, Institute of Europe, Russian Academy of Sciences. Address: 11-3, Mokhovaya str., Moscow, Russia, 125009. E-mail: vladisbelov@yandex.ru.

Abstract. The events of 2020 had a significant impact on all aspects of political and economic cooperation between Germany and Russia. The year began with a constructive political dialogue 
on a number of different international issues. However, in the second half of the year, when the FRG was the chairman of the Council of the European Union, it found itself in a deep crisis. The main reason is the so-called «The Navalny factor». At the same time, Berlin proposed to build relations with Russia in the field of security from a position of strength. The coronavirus pandemic has prompted Berlin and Moscow to restrict capital and labor mobility. In the spring, there was a sharp drop in world oil prices. This negatively affected the mutual trade flows. The volume of foreign trade has dropped significantly. Against this background, the investment activity of German companies in the Russian regions has been continued. A new area of cooperation has emerged - hydrogen energy. In September 2020, the Year of Germany began in Russia, and in December - the cross Year of Economy and Sustainable Development. In the first part, the author analyzes the political results of 2020 and the beginning of 2021 and assesses the medium-term prospects of German-Russian cooperation in the field of politics. The second part deals with the economic aspects of cooperation.

Key words: Germany, Russia, the European Union, political dialogue, German-Russian cooperation, security.

DOI: http://dx.doi.org/10.15211/vestnikieran120217080 